\begin{tabular}{|l|l|}
\hline JITAS & $\begin{array}{l}\text { JAGROS Journal of Agrotechnonogy and Science } \\
\text { Jurnal Agroteknologi dan sains } \\
\text { Fakultas Pertanian, Universitas Garut } \\
\text { P ISSN : 2775-0485, E ISSN : 2548-7752 }\end{array}$ \\
\hline
\end{tabular}

\title{
Pengaruh Ekstrak Bawang Merah dan Air Kelapa terhadap Pematahan Dormansi Biji dan Pertumbuhan Kecambah Bidara Ziziphus nummularia (Rhamnaceae)
}

\author{
Effect of Shallot Extract and Coconut Water on Seed Dormancy-reaking and \\ Seedling Growth of Jujube Ziziphus nummularia (Rhamnaceae)
}

\author{
Novriza Sativa $^{1)} *$, Sri Gustini ${ }^{1)}$, Rama Adi Pratama ${ }^{1)}$, Hanny Hidayati Nafi'ah ${ }^{1 \text {, }}$ \\ Dadi Nurdiana ${ }^{1)}$, Risha Amilia Pratiwi ${ }^{2)}$ \\ Program Studi Agroteknologi, Fakultas Pertanian, Universitas Garut, \\ Jl. Raya Samarang No 52A Garut $44151^{1)}$ \\ Pusat Riset Konservasi Tumbuhan dan Kebun Raya, Badan Riset dan Inovasi \\ Nasional, Jl. M.H. Thamrin No.8 Jakarta Pusat ${ }^{2)}$ \\ Email : *novrizasativa@uniga.ac.id
}

\begin{abstract}
Abstrak
Bidara (Ziziphus nummularia (Brum.f.) Wight \& Arn.) merupakan tumbuhan yang memiliki beragam manfaat, termasuk sebagai obat. Akan tetapi, informasi mengenai teknik budidaya bidara masih terbatas. Tumbuhan ini juga relatif sulit dibudidaya secara generatif karena memiliki lapisan endokarp yang keras sehingga dormansi bijinya sulit untuk dipatahkan. Beragam zat pengatur tumbuh (ZPT) dikembangkan untuk mematahkan dormansi biji. Ekstrak bawang merah dan air kelapa mengandung ZPT yang diketahui dapat mematahkan dormansi biji beberapa jenis tumbuhan. Akan tetapi penggunaan ekstrak bawang merah dan air kelapa terhadap pematahan dormanis biji bidara belum pernah dipublikasikan. Penelitian ini bertujuan untuk menentukan pengaruh ekstrak bawang merah dan air kelapa terhadap pematahan dormansi biji dan pertumbuhan kecambah bidara. Penelitian ini dilakukan di Garut pada bulan Juli sampai Agustus 2021. Rancangan penelitian menggunakan Rancangan Acak Kelompok Non Faktorial dengan 6 perlakuan dan 4 ulangan. Perlakuan terdiri dari A1: air kelapa, perendaman selama 12 jam, A2: air kelapa, 24 jam, A3: air kelapa, 36 jam, A4: ekstrak bawang merah, 12 jam, A5: ekstrak bawang merah, 24 jam, A6: ekstrak bawang merah, 36 jam. Hasil penelitian menunjukkan bahwa pada perlakuan dengan air kelapa, durasi perendaman biji terbaik adalah 24 jam karena menghasilkan jumlah kecambah normal terbanyak dan pertumbuhan kecambah paling cepat yang diamati berdasarkan tinggi, panjang, dan bobot kecambah. Pada perlakuan dengan ekstrak umbi bawang merah, semakin lama perendaman biji, pertumbuhan kecambah semakin cepat yang diamati berdasarkan tinggi dan panjang kecambah serta panjang akar, akan tetapi jumlah kecambah normal menurun. Air kelapa lebih baik dibandingkan ekstrak bawang merah dalam menghasilkan jumlah kecambah normal. Ekstrak bawang merah lebih baik dibandingkan air kelapa dalam mempercepat pertumbuhan kecambah. Lebih lanjut, penelitian ini dapat menjadi dasar dalam pengembangan teknik budidaya bidara secara generatif.
\end{abstract}

Kata Kunci : biji ortodoks, perkecambahan bidara, tanaman obat, ZPT alami 


\begin{abstract}
Jujube (Ziziphus nummularia (Brum.f.) Wight \& Arn.) is a plant that has various benefits, including as a medicine. However, information about jujube cultivation techniques is still limited. This plant is also relatively difficult to cultivate because it has a hard endocarp layer, so the dormancy of the seeds is difficult to break. Various plant growth regulators (PGR) were developed to break seed dormancy. Shallot extract and coconut water contain PGR, which is known to break the seed dormancy of several types of plants. However, onion extract and coconut water on the dormant breaking of jujube seeds has never been published. This study aimed to determine the effect of onion extract and coconut water on the breaking of seed dormancy and growth of jujube sprouts. This research was conducted in Garut from July to August 2021. The research used a nonfactorial randomized block design with six treatments and four replications. The treatments consisted of A1: coconut water, soaking for 12 hours, A2: coconut water, 24 hours, A3: coconut water, 36 hours, A4: onion extract, 12 hours, A5: onion extract, 24 hours, A6: extract onion, 36 hours. The results showed that in the treatment with coconut water, the best duration of soaking the seeds was 24 hours because it produced the highest number of regular sprouts, and the fastest sprout growth was observed based on height, length, and weight of sprouts. In the treatment with onion bulb extract, the more prolonged the soaking of the seeds, the faster the growth of sprouts was observed based on the height and length of the sprouts and root length, but the number of usual sprouts decreased. Coconut water was better than onion extract in producing the usual sprouts. Shallot extract was better than coconut water in accelerating sprout growth. Furthermore, this research can be the basis for developing generative jujube cultivation techniques.
\end{abstract}

Keywords : jujube germination, medicinal plants, natural PGR, orthodox seeds

\title{
1. Pendahuluan
}

Z. nummularia merupakan jenis tumbuhan yang berasal dari wilayah Mediterania, India, dan Arab (Govaerts et al., 2021). Tumbuhan ini kemudian tersebar di daerah India, Arab Saudi, Pakistan, Israel, Qatar, Yordania, Iran, Irak, Afghanistan, Belanda, juga termasuk di wilayah Asia seperti Nepal, Kamboja, Myanmar, Thailand, dan Indonesia (GBIF, 2022). Di Indonesia, wilayah persebaran alami tumbuhan ini meliputi Sumbawa (Nusa Tenggara Barat) (Zohary, 1972; Heyne, 1987), Pulau Komodo (Nusa Tenggara Barat), Pulau Timor Timur, Pantai Jasri (Bali), dan Pulau Kangean (Jawa Timur) (Bijmoer et al., 2021).

Tumbuhan yang dikenal di Indonesia sebagai bidara ini memiliki banyak manfaat, di antaranya buahnya dapat dikonsumsi dan mengandung nutrisi tinggi (Aggarwal et al., 2018), sistem perakarannya melimpah dan kuat sehingga tumbuhan ini digunakan dalam kegiatan restorasi dan rehabilitasi lahan (Sudhersan et al., 2016), selain itu berbagai bagian tumbuhan bidara berpotensi sebagai antioksidan, antimikroba, antidiare, antidiabetes, hepatoprotektif, antikanker dan antidepresan. Daun bidara juga umum 
digunakan masyarakat untuk mengawetkan daging karena mampu merusak dinding sel bakteri penyebab pembusukan daging (Siregar, 2020).

Dengan beragam potensi dan pemanfaatannya, tumbuhan bidara belum dibudidayakan secara luas oleh masyarakat Indonesia. Informasi mengenai metode perbanyakan tumbuhan bidara masih terbatas. Selain itu, biji bidara juga relatif sulit dikecambahkan. Pematahan dormansi biji marga Ziziphus, khususnya Z. nummularia, belum banyak diteliti. Pengelupasan endokarp pada biji $Z$. nummularia dapat meningkatkan persentase keberhasilan germinasi (Hussain et al., 1993). Selain itu, persentase germinasi biji $Z$. nummularia lebih tinggi dalam kondisi gelap (Hussain et al., 1993). Penelitian lain menyebutkan bahwa perlakuan skarifikasi biji Z. nummularia dengan kertas amplas menyebabkan $65 \%$ biji berhasil bergerminasi. Adapun perendaman dengan asam sulfur selama 10 menit hanya menghasilkan $45 \%$ biji yang mampu bergerminasi (Yazdanpanah et al., 2012).

Salah satu metode yang dapat digunakan dalam memecah dormansi biji adalah perendaman dalam Zat Pengatur Tumbuh (ZPT). ZPT merupakan senyawa organik bukan hara yang dalam jumlah sedikit dapat mendukung, menghambat, atau mengubah proses fisiologi tumbuhan (Hendriyani, 2007). Berdasarkan sumbernya, ZPT diperoleh secara alami maupun hasil sintetis. Penggunaan ZPT alami relatif lebih menguntungkan dibandingkan ZPT sintetis karena lebih murah, mudah diperoleh, dengan efektivitas yang tidak berbeda dengan ZPT sintesis.

Ekstrak umbi bawang merah (Allium cepa L.) merupakan salah satu sumber ZPT alami karena mengandung vitamin B1, tiamin, riboflavin, asam nikotinat, auksin, dan rhizokalin yang dapat merangsang pertumbuhan akar (Rahayu dan Berlian, 1999). Pada kelapa sawit, perendaman benih selama 6 jam dalam ekstrak bawang merah konsentrasi $100 \%$ menyebabkan pematahan dormansi (Pratama, 2018). Ekstrak bawang merah juga meningkatkan pertumbuhan bibit pada lada panjang karena mengandung auksin yang berpengaruh pada pemanjangan sel (Siswanto, 2019).

Air kelapa hijau sebagai ZPT mengandung hormon auksin dan sitokinin yang mendukung pembelahan sel sehingga merpercepat pembentukan tunas dan pemanjangan batang pada tumbuhan (Lawalata, 2011). Air kelapa hijau tidak hanya mengandung hormon pertumbuhan, tetapi juga mengandung nutrisi yang dibutuhkan oleh tumbuhan (Darmanti dan Raharjo, 2009). Perendaman biji delima (Punica granatum L.) dalam air kelapa konsentrasi 100\% selama 12 jam mematahkan dormansi biji tersebut (Sumbari, 2020). Pada pinang, perendaman biji selama 24 jam dalam air kelapa $100 \%$ meningkatkan daya kecambah pinang menjadi 98,66\% (Hidayat, 2000).

Sampai tahun 2021 belum ada penelitian mengenai metode pemecahan dormansi biji bidara Z. nummularia dengan menggunakan ZPT alami maupun sintesis. Oleh karena itu, penelitian ini bertujuan untuk menentukan pengaruh perendaman biji dalam ekstrak umbi bawang merah dan air kelapa terhadap keberhasilan pematahan dormansi biji $Z$. 
nummularia. Lebih jauh, hasil penelitian ini dapat menjadi dasar untuk pengembangan teknik budidaya bidara.

\section{Metodologi}

\section{Waktu dan Tempat}

Penelitian ini dilakukan pada bulan Juli sampai Agustus 2021 di Desa Pataruman Tarogong Kidul-Garut. Lokasi ini memiliki ketinggian 731 meter diatas permukaan laut (mdpl).

\section{Bahan dan Alat}

Bahan yang digunakan selama penelitian adalah biji bidara (Ziziphus nummularia (Brum.f) Wighrt \& Arn) hasil determinasi (lampiran 1), tanah organik (Merk: Media Tanaman Organik), air kelapa hijau, dan umbi bawang merah. Alat yang digunakan mencakup baki semai, penyiram, penggaris, gelas ukur, alat tulis, kamera, label, alat kukus, blender, timbangan, tisu, termometer, dan pengukur kelembapan.

\section{Metode Penelitian}

Metode yang digunakan dalam penelitian ini adalah Rancangan Acak Kelompok (RAK) Non Faktorial dengan perlakuan dua jenis ZPT alami, yaitu air kelapa dan ekstrak umbi bawang merah (A), serta tiga variasi durasi perendaman, yaitu 12, 24, dan 36 jam. Kelompok perlakuan dalam penelitian ini adalah sebagai berikut:

A1: air kelapa perendaman 12 jam

A2: air kelapa perendaman 24 jam

A3: air kelapa perendaman 36 jam

A4: ekstrak bawang merah perendaman 12 jam

A5: ekstrak bawang merah perendaman 24 jam

A6: ekstrak bawang merah perendaman 36 jam

Perlakuan diulang sebanyak 4 kali sehingga terdapat 24 plot baki dengan ukuran masingmasing baki 54 x $28 \mathrm{~cm}$. Jumlah populasi per plot sebanyak 25 biji, sehingga total biji keseluruhan yang digunakan adalah 600 biji._Air kelapa dan ekstrak bawang merah yang digunakan adalah $100 \%$ tanpa campuran apapun.

Secara umum, metode penelitian meliputi pengumpulan buah bidara, pembersihan, pengeringan, sortasi, dan skarifikasi biji secara fisik, pembuatan ekstrak umbi bawang merah dan larutan kelapa hijau, perendaman biji, persiapan media tanam, pemeliharaan, pengamatan, dan analisis data.

\section{a) Pengumpulan Buah Bidara}


Buah bidara dikumpulkan dari tumbuhan yang berusia sekitar 3-4 tahun. Masa panen buah bidara sejak berbunga kurang lebih enam bulan. Buah yang dikumpulkan adalah buah yang telah matang secara fisiologis dengan ciri berwarna kecoklatan.

\section{b) Pembersihan, Pengeringan, Sortasi Biji Bidara dan Skarifikasi Fisik}

Biji dipisahkan dari daging buah kemudian direndam dalam air bersih untuk memisahkan biji yang bagus, dengan ciri biji tidak mengambang. Setelah dibersihkan, biji dikeringkan di tempat yang terkena sinar matahari selama tiga hari. Waktu pengeringan adalah mulai pukul 08.00 - 16.00 WIB. Setelah kering, biji disortir berdasarkan ukuran. Biji yang digunakan dalam penelitian ini harus memiliki diameter yang seragam. Pada setiap sisi biji yang telah disortir dilakukan skarifikasi di bagian ujungnya dengan menggunakan amplas paling kasar sebanyak masing-masing sepuluh kali gesekan.

\section{c) Pembuatan Ekstrak Umbi Bawang Merah dan Kelapa Hijau}

\section{Ekstrak Umbi Bawang Merah}

Umbi bawang merah dikupas, dibersihkan dari kotoran, dan dicuci. Umbi kemudian diiris untuk mempermudah proses blender. Setelah halus, ekstrak disaring dan dikumpulkan hingga mencapai $100 \mathrm{ml}$. Ekstrak umbi bawang merah ini adalah larutan dengan konsentrasi 100\% tanpa pengenceran.

\section{Larutan Air Kelapa}

Air kelapa yang digunakan adalah berasal dari kelapa muda dan tanpa pengenceran (konsentrasi 100\%). Setelah kelapa dibersihkan dari sabutnya, air disaring terlebih dahulu untuk menghilangkan ampas yang tersisa.

\section{d) Perendaman Biji}

Biji bidara yang diskarifikasi direndam dalam larutan ekstrak umbi bawang merah dan air kelapa sesuai dengan lama perlakuan, yaitu 12 jam, 24 jam dan 36 jam.

\section{e) Persiapan Media Tanam dan Penanaman}

Media tanam yang akan digunakan terlebih dahulu dikukus selama 30 menit untuk menghindari kontaminasi jamur atau mikroba lainnya. Baki semai berukuran 54 x $28 \mathrm{~cm}$ dan memiliki 200 lubang per baki. Baki semai diisi dengan tanah sebanyak kurang lebih 1,5 kg. Pada bagian ujung baki semai diberikan batu berukuran kecil untuk menghindari erosi tanah. Biji ditanam pada baki semai dengan kedalaman kurang lebih $1.5 \mathrm{~cm}$, kemudian ditutup kembali dengan tanah.

\section{f) Pemeliharaan}


Pemeliharaan biji bidara dilakukan selama 30 hari. Setiap pagi dan sore dilakukan penyiraman agar kondisi media tanam tetap lembap. Suhu dan kelembapan di lokasi penyimpanan juga diamati.

\section{g) Pengamatan}

Parameter utama yang diamati dalam penelitian ini adalah persentase kecambah normal, persentase benih tidak tumbuh, tinggi kecambah, panjang kecambah, panjang akar, dan bobot kecambah.

1) Persentase Kecambah Normal (\% KN)

Persentase kecambah normal diamati pada akhir pengamatan (30 hari) dengan kriteria tanaman yang memiliki akar primer, hipokotil tanpa kerusakan, pertumbuhan plumula sempurna dengan warna daun hijau dan tumbuh dengan baik, atau epikotil yang sempurna dengan kuncup normal (Sutopo, 2012).

$$
\% \mathrm{KN}=\frac{\text { Jumlah kecambah normal }}{\text { jumlah benih yang diuji }} \times 100 \%
$$

2) Persentase Benih Tidak Tumbuh (\% BTT)

Benih tidak tumbuh diamati diakhir waktu pengamatan. Benih tidak tumbuh menunjukkan jumlah benih yang mati atau tidak tumbuh pada periode waktu tertentu. Perhitungan persentase benih tidak tumbuh adalah :

$$
\% \mathrm{BTT}=\frac{\text { Jumlah benih mati }}{\text { Jumlah total benih yang diuji }} \times 100 \%
$$

3) Tinggi Kecambah (cm)

Tinggi kecambah diukur menggunakan penggaris dari pangkal batang perbatasan dengan akar. Pengukuran dilakukan dengan menggunakan tiga sampel dalam satu plot yang kemudian hasil pengukurannya dirata-ratakan.

4) Panjang Kecambah (cm)

Panjang kecambah dihitung dari ujung akar hingga ujung daun tertinggi. Panjang kecambah diambil dari tiga sampel dalam satu plot pada hari akhir pengamatan.

5) Panjang Akar (cm)

Panjang akar dihitung dari ujung akar hingga pangkal batang. Sampel yang diambil adalah tiga sampel pada setiap plot pada hari ke-30 hari setelah tanam (HST).

6) Bobot Kecambah (mg)

Bobot kecambah diambil dari tiga sampel pada setiap plot. Kecambah dibersihkan terlebih dahulu dari sisa tanah yang menempel kemudian ditimbang menggunakan timbangan analitik.

\section{h) Analisis Data}

Dalam penelitian ini dilakukan analisis model linier dan analisis ragam sebagai berikut: 
Vol. 6 ; No. 1 Desember 2021

Halaman 30 - 43

\section{Model Linier}

Model RAK Non Faktorial Menurut Gomez dan Gomez (2010), sebagai berikut:

$$
\mathbf{Y}_{\mathbf{i j}}=\boldsymbol{\mu}+\tau_{\mathbf{i}}+\mathrm{H}_{\mathbf{j}}+\sum_{\mathbf{i j}}
$$

Keterangan:

$\mathrm{Y}_{\mathrm{ij}}=$ Nilai pengamatan dari perlakuan ke-i dalam kelompok ke-j.

$\mu=$ Nilai tengah populasi.

$\tau_{\mathrm{i}}=$ Pengaruh hormon dari perlakuan ke-i.

$\mathrm{H}_{\mathrm{j}}=$ Pengaruh hormon dari ulangan ke-j.

$\sum_{\mathrm{ij}}=$ Pengaruh galat dari perlakuan ke-i pada ulangan ke-j.

\section{Analisis Ragam}

Berdasarkan model linier, daftar analisis ragam disusun pada Tabel 1 berikut ini.

Tabel 1. Analisis Ragam Percobaan

\begin{tabular}{cccccc}
\hline Sumber Ragam & $\mathrm{DB}$ & $\mathrm{JK}$ & $\mathrm{KT}$ & $\mathrm{F}_{\text {hitung }}$ & $\mathrm{F}_{0,05}$ \\
\hline Ulangan (r) & 3 & $\sum \mathrm{xi}^{2} / \mathrm{t}-\mathrm{FK}$ & $\mathrm{JK}_{\mathrm{ul}} / \mathrm{DB}_{\mathrm{ul}}$ & $\mathrm{KT}_{\mathrm{ul}} / \mathrm{KT}_{\mathrm{gal}}$ & 3,29 \\
Perlakuan (t) & 5 & $\sum \mathrm{xi}^{2} / \mathrm{r}-\mathrm{FK}$ & $\mathrm{JK}_{\mathrm{per}} / \mathrm{DB}_{\mathrm{per}}$ & $\mathrm{KT}_{\mathrm{per}} / \mathrm{KT}_{\mathrm{gal}}$ & 2,90 \\
Galat & 15 & $\mathrm{JK}_{\mathrm{tot}}-\mathrm{JK}_{\mathrm{ul}}-\mathrm{JK}_{\mathrm{per}}$ & $\mathrm{JK}_{\mathrm{gal}} / \mathrm{DB}_{\mathrm{gal}}$ & & \\
\hline Total & 23 & $\sum \mathrm{x}_{\mathrm{ij}}{ }^{2}-\mathrm{FK}$ & & & \\
\hline
\end{tabular}

Sumber: Gomez dan Gomez (2010)

Untuk mengetahui tingkat perbedaan masing-masing perlakuan digunakan uji $\mathrm{F}$ dengan kaidah pengambilan keputusan berikut ini:

$$
\begin{gathered}
\mathrm{F}_{\text {hitung }} \leq \mathrm{F}_{0,05}=\text { tidak berbeda nyata dan diberi tanda }\left({ }^{\mathrm{ns}}\right) \\
\mathrm{F}_{\text {hitung }} \geq \mathrm{F}_{0,05}=\text { berbeda nyata dan diberi tanda }\left(^{*}\right)
\end{gathered}
$$

Apabila F hitung lebih besar dari F tabel, pengujian dilanjutkan dengan uji lanjut Duncan dengan taraf kesalahan 5\% sebagai berikut:

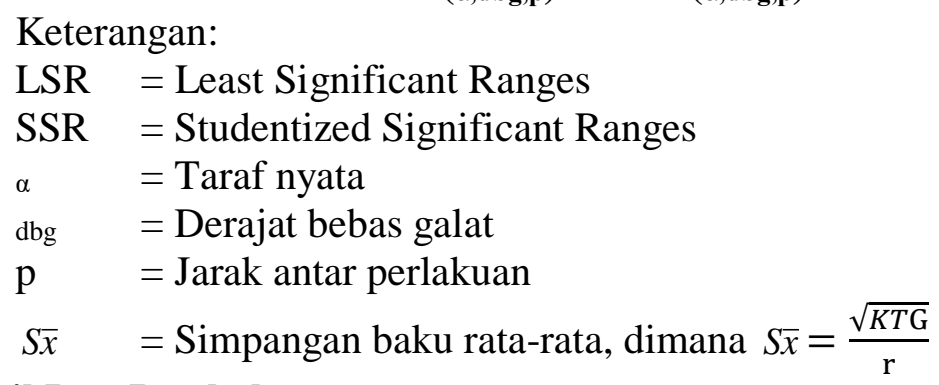

\section{Hasil Dan Pembahasan}

\section{1) Persentase Kecambah Normal}

Perendaman biji bidara dalam air kelapa hijau 100\% selama 24 jam menyebabkan persentase perkecambahan tertinggi, yaitu $20 \%$, berbeda signifikan dibandingkan dengan perlakuan perendaman yang lebih singkat, yaitu selama 12 jam (Tabel 2). Hasil serupa 
didapatkan dari penelitian terhadap perkecambahan pada biji pinang, yaitu perendaman biji dengan air kelapa selama 24 jam menghasilkan tingkat perkecambahan tertinggi (Hidayat, 2000). Untuk durasi perendaman yang sama, yaitu 24 jam, air kelapa menghasilkan kecambah normal yang lebih banyak dibandingkan ekstrak umbi bawang merah. Pada perlakuan dengan ekstrak umbi bawang merah $100 \%$, semakin panjang durasi perendaman biji, jumlah kecambah normal yang dihasilkan semakin menurun secara signifikan (Tabel 2).

Tabel. 2 Analisis Data Pengamatan Kecambah Normal 30 HST

\begin{tabular}{lcc}
\hline Perlakuan & rata-rata & notasi \\
\hline A1 (air kelapa12 jam) & 15.00 & $\mathrm{ab}$ \\
A2 (air kelapa 24 jam) & 20.00 & $\mathrm{c}$ \\
A3 (air kelapa 36 jam) & 17.00 & $\mathrm{bc}$ \\
A4 (ekstrak bawang merah 12 jam) & 17.00 & $\mathrm{bc}$ \\
A5 (ekstrak bawang merah 24 jam) & 14.00 & $\mathrm{ab}$ \\
A6 (ekstrak bawang merah 36 jam) & 12.00 & $\mathrm{a}$ \\
\hline
\end{tabular}

Keterangan: angka rata-rata yang ditandai huruf yang sama menunjukkan tidak berbeda nyata menurut uji DMRT pada taraf 5\%

\section{2) Persentase Benih Tidak Tumbuh}

Perendaman biji dengan air kelapa selama 24 jam menghasilkan jumlah kecambah tidak tumbuh paling sedikit, yaitu $80 \%$, lebih kecil secara signifikan dibandingkan perendaman yang lebih singkat, yaitu selama 12 jam. Jumlah kecambah tidak tumbuh terbanyak dihasilkan dari perendaman dengan ekstrak umbi bawang merah selama 36 jam (Tabel 3). Hasil ini sejalan dengan persentase perkecambahan normal pada Tabel 2.

Kandungan sitokinin pada air kelapa berperan dalam memacu pembelahan sel. Hormon ini dapat mempengaruhi asam nukleat untuk sintesis enzim dan mengatur aktivitas hormon sitokinin yang juga berperan dalam pembelahan sel sehingga radikula dapat terdorong menembus endosperm (Amirudin, 2015). Selain itu, air kelapa juga memiliki kandungan senyawa organik lain untuk pertumbuhan tanaman seperti vitamin $\mathrm{C}$, vitamin B, hormon auksin dan giberelin (Ajar, 2015). Perendaman dengan air kelapa selama 24 jam juga memicu perkecambahan biji angsan (Pterocarpus indicus) (Manurung, 2021).

Pada Tabel 2 dan 3, semakin lama durasi perendaman, persentase perkecambahan cenderung menurum. Semakin lama direndam, jumlah auksin dari air kelapa maupun ekstrak umbi bawang merah yang terserap biji bidara semakin banyak. Konsentrasi auksin yang tinggi memicu aktivitas etilen yang memberikan dampak berlawanan dengan auksin, yaitu menghambat metabolism (Lubis, 2018).

Tabel. 3 Analisis Data Pengamatan Kecambah Tidak Tumbuh

Perlakuan rata-rata




\begin{tabular}{lc}
\hline A1 (air kelapa 12 jam) & $85.00 \mathrm{bc}$ \\
A2 (air kelapa 24 jam) & $80.00 \mathrm{c}$ \\
A3 (air kelapa 36 jam) & $84.00 \mathrm{abc}$ \\
A4 (ekstrak bawang merah 12 jam) & $83.00 \mathrm{ab}$ \\
A5(ekstrak bawang merah 24 jam) & $83.00 \mathrm{ab}$ \\
A6 (ekstrak bawang merah 36 jam) & $88.00 \mathrm{c}$ \\
\hline Keterangan: angka rata-rata yang ditandai huruf yang sama \\
menunjukkan tidak berbeda nyata menurut uji DMRT pada taraf \\
5\%
\end{tabular}

\section{3) Tinggi Kecambah}

Dari Tabel 4 diketahui bahwa perendaman biji pada ekstrak umbi bawang merah dan air kelapa tidak berpengaruh pada tinggi kecambah. Meskipun demikian, perendaman biji selama 24 jam dalam air kelapa menghasilkan kecambah yang lebih tinggi dibandingkan dengan perendaman dalam air kelapa selama 12 dan 36 jam. Dibandingkan dengan air kelapa, ekstrak umbi bawang merah menghasilkan kecambah yang lebih tinggi meskipun tidak signifikan. Semakin lama waktu perendaman dengan ekstrak bawang merah, pertumbuhan kecambah semakin cepat.

ZPT merupakan senyawa organik yang bukan merupakan nutrisi yang dalam konsentrasi rendah mampu merangsang, menghambat, atau mengubah kecepatan pertumbuhan dan perkembangan tumbuhan. Biji setiap jenis tumbuhan memiliki kemampuan masing-masing dalam hal kecepatan tumbuh dan penyerapan ZPT (Lestari, 2011).

$\underline{\text { Tabel. } 4 \text { Hasil Analisis Persentase Tinggi Kecambah }}$

\begin{tabular}{lc}
\hline Perlakuan & rata-rata \\
\hline A1 (air kelapa 12 jam) & $3.75 \mathrm{a}$ \\
A2 (air kelapa 24 jam) & $4.20 \mathrm{a}$ \\
A3 (air kelapa 36 jam) & $3.65 \mathrm{a}$ \\
A4 (ekstrak bawang merah 12 jam) & 4.13 \\
A5(ekstrak bawang merah 24 jam) & 4.06 \\
A6 (ekstrak bawang merah 36 jam) & 4.50 \\
\hline
\end{tabular}

Keterangan: angka rata-rata yang ditandai huruf yang sama menunjukkan tidak berbeda nyata menurut uji DMRT pada taraf $5 \%$

\section{4) Panjang Kecambah}

Pada perendaman dengan ekstrak umbi bawang merah, semakin lama durasi perendaman, panjang kecambah semakin baik meskipun tidak berbeda nyata dengan perlakuan lainnya. Perendaman dengan bawang merah cenderung menyebabkan pertambuhan panjang kecambah yang lebih baik dibandingkan air kelapa (Tabel 5). 
Diduga hormol giberilin bada umbi bawang merah mempercepat pembelahan sel sehingga ruas tanaman dan daun tumbuh lebih cepat (Siregar, 2018).

Pada perendaman biji dengan air kelapa, durasi perendaman selama 24 jam menyebabkan pemanjangan kecambah paling cepat dibandingkan durasi perlakuan lainnya. Kandungan auksin dalam air kelapa dapat membantu sel untuk membelah secara cepat untuk berkembang menjadi tunas dan batang (Pamungkas et al., 2009).

\section{Tabel. 5 Hasil Analisis Persentase Panjang Kecambah}

\begin{tabular}{lc}
\hline Perlakuan & rata-rata \\
\hline A1 (air kelapa 12 jam) & $6.88 a$ \\
A2 (air kelapa 24 jam) & $7.16 a$ \\
A3 (air kelapa 36 jam) & $6.81 a$ \\
A4 (ekstrak bawang merah 12 jam) & $7.33 a$ \\
A5 (ekstrak bawang merah 24 jam) & $7.40 a$ \\
A6 (ekstrak bawang merah 36 jam) & $8.02 a$ \\
\hline
\end{tabular}

Keterangan: angka rata-rata yang ditandai huruf yang sama menunjukkan tidak berbeda nyata menurut uji DMRT pada taraf $5 \%$

\section{5) Panjang Akar}

Durasi perendaman biji dalam air kelapa berbanding terbalik dengan panjang akar (Tabel 6). Diduga, ZPT alami yang ada pada air kelapa jika terpapar terlalu lama dapat memberikan efek negatif untuk pertumbuhan akar. Secara umum, perendaman biji dengan ekstrak umbi bawang merah menyebabkan pertumbuhan akar yang lebih cepat dibandingkan dengan perendaman biji dalam air kelapa meskipun tidak ada perbedaan pengaruh yang signifikan pada seluruh perlakuan. Diduga dalam ekstrak umbi bawang merah selain terkandung ZPT auksin yang merangsang pertumbuhan akar juga terdapat vitamin B1 yang dapat membantu penguraian karbohidrat menjadi energi. Inisiasi akar merupakan mekanisme yang memerlukan energi berupa glukosa, nitrogen, dan senyawa lain dalam jumlah yang cukup (Siregar, 2018).

Tabel. 6 Hasil Analisis Persentase Panjang Akar

\begin{tabular}{lc}
\hline Perlakuan & $\begin{array}{c}\text { rata- } \\
\text { rata }\end{array}$ \\
\hline A1 (air kelapa 12 jam) & $2.98 \mathrm{a}$ \\
A2 (air kelapa 24 jam) & $2.94 \mathrm{a}$ \\
A3 (air kelapa 36 jam) & $2.89 \mathrm{a}$ \\
\hline
\end{tabular}




\begin{tabular}{|c|c|}
\hline A4 (ekstrak bawang merah 12 jam) & $3.20 \mathrm{a}$ \\
\hline A5(ekstrak bawang merah 24 jam) & $3.33 \mathrm{a}$ \\
\hline A6 (ekstrak bawang merah 36 jam) & $3.52 \mathrm{a}$ \\
\hline
\end{tabular}

\section{6) Bobot Kecambah}

Secara umum, perendaman biji dengan ekstrak umbi bawang merah menghasilkan kecambah dengan bobot lebih berat dibandingkan dengan perendaman biji dalam air kelapa meskipun tidak ada perbedaan pengaruh yang signifikan pada seluruh perlakuan. Tetapi setelah 36 jam, perendaman biji dengan ekstrak umbi bawang merah menghasilkan bobot kecambah yang lebih rendah (Tabel 7). Diduga perendaman terlalu lama dapat bersifat toksik bagi tumbuhan sehingga dapat menghambat pertumbuhan tanaman dan berpengaruh pada bobot kecambah (Berlintina, 2019).

Tabel. 7 Hasil Analisis Persentase Bobot Kecambah

\begin{tabular}{lc}
\hline Perlakuan & $\begin{array}{c}\text { rata- } \\
\text { rata }\end{array}$ \\
\hline A1 (air kelapa 12 jam) & $137.50 \mathrm{a}$ \\
A2 (air kelapa 24 jam) & $147.50 \mathrm{a}$ \\
A3 (air kelapa 36 jam) & $127.50 \mathrm{a}$ \\
A4 (ekstrak bawang merah 12 jam) & $135.00 \mathrm{a}$ \\
A5 (ekstrak bawang merah 24 jam) & $192.50 \mathrm{a}$ \\
A6 (ekstrak bawang merah 36 jam) & $152.50 \mathrm{a}$ \\
\hline
\end{tabular}

Keterangan angka rata-rata yang ditandai huruf yang sama menunjukkan tidak berbeda nyata menurut uji DMRT pada taraf $5 \%$

\section{Kesimpulan}

Pada perlakuan dengan air kelapa, durasi perendaman biji terbaik adalah 24 jam karena menghasilkan kecambah normal terbanyak dan pertumbuhan kecambah paling cepat yang diamati berdasarkan tinggi, panjang, dan bobot kecambah. Pada perlakuan dengan ekstrak umbi bawang merah, semakin lama perendaman biji, pertumbuhan kecambah semakin cepat yang diamati berdasarkan tinggi dan panjang kecambah serta panjang akar, akan tetapi jumlah kecambah normal menurun. Air kelapa lebih baik 
dibandingkan ekstrak bawang merah dalam menghasilkan jumlah kecambah normal. Ekstrak bawang merah lebih baik dibandingkan air kelapa dalam mempercepat pertumbuhan kecambah.

\section{Daftar Pustaka}

Adzu B, Haruna AK. 2007. Studied on the use of Ziziphus spina-christi against pain in rast and mice. Afr. J. Biotechnol, 6(11), 1317-1324.

Allan, Ali.E.A. 2012. Ziziphus spina-christi "Christ's Thorn": In Vitro Callus and Cell Culture, Qualitative Analysis of Secondary Metabolites and Bioassay-Palestine Polytechnic. University Deanship of Higher Studies and Scientific Research.

Amirudin, Hastuti, E. D dan Prihastanti, E. 2015. Pengaruh Jenis dan Konsentrasi Larutan Perendaman Alami Terhadap Perkecambahan Biji dan Pertumbuhan Bibit Kelapa Sawit (Elaeis guineensis Jacq), Jurnal Biologi, 4(1), pp. 93-115.

Arditya Pratama, T. N. B. S dan T. S. 2018. Pengaruh Ekstrak Bawang merah dan Tauge Serta Lama perendaman terhadap Pertumbuhan Bibit Kelapa Sawit Di PRE NURSERY', Agromast, 3(1).

Ajar, Siti. 2015. Pengaruh Konsentrasi Air Kelapa dan Lama Perendaman Terhadap Perkecambahan Benih Padi (Oryza sativa L.) Kadaluarsa. Fakultas Pertanian Universitas Teuku Umar Meulaboh Aceh Barat. Aceh Barat.

Aggarwal, B., Sharma, P., \& Lamba, HS. (2018). Ethnobotanical, phytochemical and pharmacological properties of Zizyphus nummularia (Burm. F.): A Review. International Journal of Phytomedicine, 10(3), 137-147. https://doi.org/10.5138/09750185.2265

Basri, H. 2005. Pengaruh Air Kelapa Muda Terhadap Perkecambahan Biji Wijen (Sesanum indicum L.). Program Studi Pendidikan Biologi STKIP PGRI Sumbar.Padang.

Berlintina, D. 2019. Pengaruh Jenis dan Frekuensi Pemberian Zat Pengatur Tumbuh Alami Pada Pertumbuhan Seedling Manggis (Garcinia mangostana L.). (Skipsi). Jurusan Agroteknologi Fakultas Pertanian Universitas Lampung. Lampung.

Bijmoer R, Scherrenberg M, Creuwels J (2021). Naturalis Biodiversity Center (NL) Botany. Naturalis Biodiversity Center. Occurrence dataset https://doi.org/10.15468/ib5ypt accessed via GBIF.org on 2022-01-18. https://www.gbif.org/occurrence/2514310837

Chika sumbari., R. thalib dan aswaldi anwar. 2020. Upaya Pematahan Dormansi Benih Delima (Punica granatum L.) Dengan Air Kelapa, Menara Ilmu, XIV(16932617), pp. 2528-7613.

D Dahiru. 2010. Evaluation of The Antioksidan Effects of Ziziphus mauritiana Lam. Leaf Extracts againt Chronic Ethanol-Induced Hepatotoxicity In Rat Liver, African Journal Traditional Complementary Alternative Mediines (CAM).

Djamhuri, E. 2011. Pemanfaatan Air Kelapa untuk Meningkatkan Pertumbuhan Stek Pucuk Meranti Tembaga (Shorea leprosula). Jurnal Silvikultur Tropika. Vol. 02, Hal :5-8.

Darlina. (2016). Pengaruh penyiraman air kelapa (Cocos nucifera L.) terhadap pertumbuhan vegetatif lada (Piper ningrum L.). Jurnal Ilmiah Mahasiswa Pendidikan Biologi, 1(1), 20-28. 
Vol. 6 ; No. 1 Desember 2021

Halaman $30-43$

GBIF.org (18 January 2022) GBIF Occurrence Download https://doi.org/10.15468/dl.qzw5gi

Gaur dan Sharma, G. 2013. Ziziphus mauritiana Lam-An Overview, Indo American Journal of Pharmaceutical Research, 3, pp. 2231-6876.

Ghannadi A, Tavakoli N, dkk. (2013). Volatile constituents of the leaves of Ziziphus spina-christi (L.) Willd. from Bushehr, Iran. J Essen Oil Res, 15 (2): 191-198.

Gomez, K. A. dan G. A. A. 2010. Prosedur Statistik Untuk Penelitian Pertanian. kedua. Jakarta: UI Press.

Govaerts, R., Nic Lughadha, E., Black, N., Turner, R., \& Paton, A. (2021). The world checklist of vascular plants, a continuously updated resource for exploring global plant diversity. Scientific Data, 8(1), 215. https://doi.org/10.1038/s41597-021$\underline{00997-6}$

Goyal M, Nagori BP, S. D. 2012. Review on ethnomedicinal uses, pharmacological activity and phytochemical constituents of Ziziphus mauritiana (Z. jujuba Lam., non Mill), Spatula DD, 2, pp. 107-116.

Heddy, S. 1996. Hormon Tumbuhan. Jakarta : PT. Raja Grafindo Persada. 97 hal

Hendriyani, E. 2007. Uji Media Pada Perkecambahan Biji Anggrek Phapiopedilum javanicum (Reinw. ex Lindl.) Pfitzer. Secara In Vitro. Bali: UPT Balai Konservasi Tumbuhan Kebun Raya ' Eka Karya' Bali-LIPI.

Heyne, K. 1987. Tumbuhan Berguna Indonesia Jilid III. Jakarta: Balai Penelitian dan Pengembangan Kehutanan.

Hidayat, 2000. Pengaruh Lama Perendaman Benih Pinang (Areca catecu L.) Dalam Air Kelapa Muda Terhadap Perkecambahannya. Universitas Riau.

Hussain, F., Shaukat, S., Ilahi, I., Qureshi, M.Z., 1993. Germination promotion of Ziziphus nummularia. Hamdard 36, 46-55

Komala and Selvi. 2014. Pengaruh Letak biji dalam Buah dan Tiga Macam Pupuk Organik Terhadap daya Tumbuh dan Pertumbuhan Bibit nangka (Artocarpus integra L.), Jurnal Vegetalika, 3(4).

Kristina, N. N. dan S. F. S. 2012. Pengaruh Air Kelapa Terhadap Multiplikasi Tunas In Vitro, Produksi Rimpang dan Kandungan Xanthorrhizol Temulawak Di Lapangan, Jurnal Littri, 18(3), pp. 125-134.

Lawalata, I. J. 2011. Pemberian Beberapa Pemberian ZPT Terhadap Regenerasi Tanaman Gloxinia (Siningia speciosa) dari Eksplan Batang dan Daun secara In Vitro. J.

Leadem, C. L. 1997. Dormancy-Unlocking Seed Secret. In : Landis, T.D., Thomson, J.R. Tech. Coords. National Proceedings, Forest and Conservation Nursery Associations. Gen. Tech. Rep. PNW-G TR-419. Portland, OR : U.S.

Lestari, B. L. (2011). Kajian Zat Pengatur Tumbuh Atonik dalam Berbagai Konsentrasi dan Interval Penyemprotan terhadap Hasil Tanaman Bawang (Allium ascolanicum L.) Fakultas Pertanian Universitas Mochamad Soroedji Jember. J. Rekayasa, Vol: 4 (1) April 2011.

Listyana, N. H., Wulandari, I. S. dan Widyantoro. 2020. Pengaruh Konsentrasi Air Perasan Bawang Merah dan Bawang Putih Serta Waktu Perendaman Terhadap Perkecambahan Benih Sambiloto (Andrographis paniculata (Burm.f.) Nees), Jurnal Agroteknologi, 4(1), pp. 12-17.

Lubis, R. R., T. Kurniawan dan Zuyasna. 2018. Invigorasi Benih Tomat Kadaluarsa dengan Ekstrak Bawang Merah pada Berbagai Konsentrasi dan Lama Perendaman. Jurnal Ilmiah Mahasiswa Pertanian, 3 (4): 175-184.

Manurung, M. A., Mardhiansyah, M dan Sribudiani, E. 2021. Pengaruh Lama 
perendaman Terhadap Perkecambahan Semai Angsana (Pterocarpus indicus L.)., Jurnal ilmu-ilmu kehutanan, 5(1), pp. 8-10.

Marfirani dan Melisa. 2014. Pengaruh Pemberian Berbagai Konsentrasi Filtrat Umbi Bawang Merah dan Rootone-F terhadap Pertumbuhan Stek Melati "Rato Ebu, Lentera Bio, 3(1), pp. 73-76.

Pamungkas, F.T., Darmanti, S., dan Raharjo, B. 2009. Pengaruh Konsentrasi dan Lama Perendaman Dalam Supernatan Kultur Bacilus Sp.2 DUCC-BR-KI 3 Terhadap Pertumbuhan Stek Horizontal Batang Jarak Pagar (Jatropha curcas L.).

Rahayu, E dan Berlian, N. 1999. Bawang Merah. Jakarta: PT Penebar Swadaya.

Sadjad, S. 1980. Panduan Mutu Benih Tanaman Kehutanan di Indonesia. Bogor: IPB.Saied, S. A. Gebauer, J. and Hmmar, K. 2008. Ziziphus spina-christi

Sudhersan, C., Jibi, S., \& Ashkanani, J. (2016). Ziziphus: A highly potential multipurpose woody perennial for desert environmental rehabilitation. Acta Horticulturae, 1116, 9-14. https://doi.org/10.17660/ActaHortic.2016.1116.2

Tjitrosoepomo, Gembong. 2010. Taksonomi Tumbuhan Spermatophyta. Yogyakarta: Gajah Mada University press

Rost, et al. 1998. Plant Biology. California: Wadsworth Publishing Company.

Wareing, P and Philips, I. D. J. (1981) The Control of Growth and Differentiation in plants. New York: Pergamon Press.

Warisno, 2003. Budi Daya Kelapa Genjah. Yogyakarta : Kanisius

Yazdanpanah, E., Armand, N., Mohsenzadeh, S., Moradshahi, A., Ahmadi, K., \& Jahantab, E. (2012). Seed dormancy breaking of Ziziphus nummularia. Advances in Environmental Biology, 2681+. https://link.gale.com/apps/doc/A336175989/AONE?u=anon $822 \mathrm{c} 7 \mathrm{~b} 62 \&$ sid=go ogleScholar\&xid=c030c2b6

Yuniarti, N. 2006. Kriteria masak fisiologis buah dan berat 1000 butir benih kenari (Canarium sp.). Prosiding Seminar Benih untuk Rakyat: Menghasilkan dan Menggunakan Benih Bermutu Secara Mandiri. Bogor: Balai Penelitian Teknologi Perbenihan.

Zohary, M. 1972. Flora Palestina. II. Jerusalem: The Israel Academy of Science and Humanities. Israel. 